\title{
The Role of Logistics in Food Waste Reduction in Wholesalers and Small Retailers of Fruits and Vegetables: A Multiple Case Study
}

\author{
Patrícia Guarnieri ${ }^{1,2}$ (D) Raiane C. C. de Aguiar ${ }^{2}$, Karim M. Thomé ${ }^{2}$ and Eluiza Alberto de Morais Watanabe ${ }^{1, *(D)}$ \\ 1 Faculty of Economy, Business Administration, Accounting and Public Policy Management, \\ Department of Business Administration, University of Brasília, Brasília 70910-900, Brazil; \\ patriciaguarnieris@gmail.com \\ 2 Faculty of Agribusiness, University of Brasília, Brasília 70910-900, Brazil; \\ raianeaguiar1@gmail.com (R.C.C.d.A.); thome.karim@gmail.com (K.M.T.) \\ * Correspondence: eluizawatanabe@unb.br
}

Citation: Guarnieri, P.; de Aguiar, R.C.C.; Thomé, K.M.; Watanabe, E.A.d.M. The Role of Logistics in Food Waste Reduction in Wholesalers and Small Retailers of Fruits and Vegetables: A Multiple Case Study. Logistics 2021, 5, 77. https://doi.org/ 10.3390/logistics5040077

Academic Editor: Robert Handfield

Received: 13 July 2021

Accepted: 7 October 2021

Published: 4 November 2021

Publisher's Note: MDPI stays neutral with regard to jurisdictional claims in published maps and institutional affiliations.

Copyright: (c) 2021 by the authors. Licensee MDPI, Basel, Switzerland. This article is an open access article distributed under the terms and conditions of the Creative Commons Attribution (CC BY) license (https:// creativecommons.org/licenses/by/ $4.0 /)$.

\begin{abstract}
Background: There is a lack of studies on the waste of fruits and vegetables covering both distributors and the retail sector. Our study advances from previous ones by proposing the analysis of local retailers of different sizes and wholesalers. Our objective was to analyze the logistical practices to reduce the waste of fruits and vegetables in wholesalers and small retailers in Federal District, Brazil. Methods: A multiple case study was conducted with 19 retailers and eight wholesalers. We administered semi-structured interviews and performed documental analysis and direct observation. Results: The findings demonstrated the leading logistical practices of handling, conservation, management and control, and consumer awareness about food waste. The type of retailer was limited to grocery stores and fruit shops, and the type of food covered only fruits and vegetables. Furthermore, we considered the food waste generated in the logistics processes and not that after consumption. Conclusions: More than a third of the food produced worldwide is lost or wasted. A considerable part of the food waste is associated with the lack of an adequate structure of the logistical processes. The results may contribute to the adoption of practices related to reducing food waste by retailers and wholesalers.
\end{abstract}

Keywords: food waste; logistics; retail; wholesale; supply chain management

\section{Introduction}

Despite the expeditiousness of world food production, the United Nations Food and Agriculture Organization [1] points out the need for a $60 \%$ increase in global food production by 2050 to meet the population's growing demands. Brazilian agricultural production has grown markedly in the last decade, facilitating the reduction of poverty and hunger in the country [2]. Specifically, in relation to fruit production, Brazil stands out as the third largest world producer, responsible for approximately 45 million tons of produce every year, with about $65 \%$ for domestic supply and the remaining $35 \%$ destined for exportation [3]. Additionally, the Brazilian vegetable chain presents various options, concentrating its production volume on the following species: potato, tomato, watermelon, lettuce, onion, and carrot [3].

Although the volume of food production in Brazil is enormous, a substantial part is wasted [4]. Brazil wastes around 41 thousand tons of food per year [5]. Worldwide, more than a third of the produced food is lost or wasted, equivalent to about 1.3 billion tons of food [6]. Among the amounts lost or wasted, 30\% corresponds to cereals; between $40 \%$ and 50\% comprises roots, fruits, vegetables, and oilseeds; $20 \%$ involves meat and dairy products; and $35 \%$ is fish. It is estimated that these foods would be enough to feed two million people [6]. Within this context, reducing food losses and waste should be a priority 
for establishing productive structures and structures of sustainable consumption [1]. The irrational use of food harms humanity [7]. Understanding food waste is crucial as it affects food chains. For example, the European Union and other high-income countries have significantly higher levels of food waste [8]. In developing countries, such as Brazil, waste is mainly linked to the initial stages of the supply chain involving harvesting, transportation, storage, and distribution [9]. About 30\% of the total vegetables that pass through the distribution centers are lost, with only $70 \%$ being marketed [10].

Analyzing the overview of worldwide studies, it is possible to verify an emphasis on the valuation of the final consumer behavior [11-13], the measurement of the wasted quantities [14,15], and the environmental and monetary impacts generated by food waste [16,17]. In Brazil, some studies have addressed food waste under the perspective of logistical bottlenecks [18]. The authors approached specifically the handling and transportation activities, verifying the rates of losses of vegetables and fruits. Other studies addressed the role of packaging and the supply chain's coordination structures to reduce food waste [19]. The use of food waste in a different production process was studied by Belik et al. [20] and Fagundes et al. [21]. Finally, some studies stressed the causes of food loss and ways to reduce food waste [22-24].

Considering this scenario, there is a lack of studies on the waste of fruits and vegetables covering both distributors and the retail sector. Thus, the present study advances from previous ones by proposing the analysis of local retailers of different sizes and wholesalers. This paper aims to analyze the best logistical practices in reducing the waste of vegetables and fruits in retailers and wholesalers located in the Federal District, Brazil. For this purpose, this study was composed of two parts: first we identified the causes of waste through a systematic literature review, considering Brazilian and international studies, and second, we carried out an analysis of multiple cases through direct qualitative interviews conducted with 19 managers/owners of fruits and vegetable stores and eight wholesalers, who supply the fruits and vegetables to the stores. The data analysis was carried out by means of categorical content analysis.

The main contribution of this paper is twofold: (i) the systematization of the best logistical practices of fruits and vegetables to avoid food waste employing a systematic literature review; (ii) the analysis of the best logistical practices to reduce the waste of fruits and vegetables adopted by retailers and wholesalers in the agri-food chain, in terms of handling, conservation, management and control, and awareness.

\section{Literature Review}

\subsection{Agri-Food Supply Chain and Food Waste}

The agri-food supply chain refers to a series of relationships in different segments that establish successive exchanges in transforming inputs into value for the final consumer [25].

The agri-food supply chain starts at the point "Before the Farms", covering the activities related to inbound logistics and companies that supply raw materials to be used in the production process in the field, such as seeds and agrochemicals. Then, there is the link "On the Farms", which considers the improvements that products still receive inside the farms: weighing, pre-washing, selection, cooling, agro industrialization, and packaging. The last link, which is the focus of this research, is the "After the Farms" phase, covering outbound logistics activities, including activities of handling, storage, warehousing, and transport. It considers attempts to sell products to industries and other distribution channels until they reach the final consumer [10].

Within the agri-food supply chain, specifically for fruits and vegetables, food waste can occur, mainly due to the high perishability of the product and incorrect handling and transportation. It is essential to point out that there are two main types of food waste. When there are losses until the process of distribution, we call them "food losses". After the distribution process in several channels (wholesalers, retailers, small stores, fairs, direct sales to consumers) and after the sales, at the consumers' residence, we call them "food waste". This study is focused on the food waste occurring in retailers and wholesalers. In 
this process, many products that individuals can still consume are discarded. The waste of fruits and vegetables is mainly associated with the behavior of wholesalers, retailers, other food sales services, and consumers [6]. Food waste encompasses all food discarded in the marketing stages by retailers and wholesalers, in which the food is discarded under full consumption conditions since it would still meet nutritional needs [9].

It is noteworthy that a considerable part of the waste is associated with the lack of adequate structure of the logistical processes involved [4], which is the focus of this study. The way the supply chain components are structured directly influences the quality of the products [25]. Furthermore, errors in demand forecast, inefficient replenishment policies, and high product quality demand can contribute to food waste [26]. Structural problems, such as planning and logistical bottlenecks, limit improvements in Brazil's fruit and vegetable supply chain stages [27]. After the harvest, food waste in Brazil is caused by improper packaging, lack of product refrigeration, improper handling, poor display of products on the shelves, deficiencies in transportation, and incorrect handling by consumers [28].

In this sense, reducing food waste is a challenge that requires enhancing the efficiency of the operations and logistics [29]. It may include infrastructure and hygiene care advances and better management and conservation of the fruits and vegetables in the market [30]. Furthermore, improvement in logistics, cold chain management, retail packaging, and consumer awareness publicity can prevent food waste [31].

\subsection{The Best Logistical Practices to Reduce Waste of Fruits and Vegetables: Systematic Literature Review on Brazilian and International Publications}

In order to get the leading logistical practices aimed at reducing the waste of fruits and vegetables, we conducted two systematic literature reviews. This section presents the results of the literature reviews, on the basis of which category construction was carried out for data collection and analysis. The description of the used protocol to select and filter papers is included in Section 3, related to methodological procedures. Table 1 shows Brazilian and international publications' analysis of best practices in logistics to reduce/avoid food waste.

Table 1. Best practices in the logistics stages to reduce and/or avoid food waste.

\begin{tabular}{|c|c|c|}
\hline Best Practices & Stage & Authors \\
\hline $\begin{array}{l}\text { Environment climatization } \\
\text { (temperature, humidity) }\end{array}$ & $\begin{array}{l}\text { Planting, transportation, } \\
\text { storage, warehousing, } \\
\text { commercialization }\end{array}$ & $\begin{array}{l}\text { Almeida et al. [24]; Ceccato and } \\
\text { Basso [32]; Tofanelli et al. [23] }\end{array}$ \\
\hline $\begin{array}{l}\text { Improvement in product } \\
\text { quality (standardization } \\
\text { and classification) }\end{array}$ & $\begin{array}{l}\text { Planting, acquisition, } \\
\text { commercialization }\end{array}$ & $\begin{array}{c}\text { Ceccato and Basso [32]; Tofanelli } \\
\text { et al. [23]; Tofanelli et al. [33]; } \\
\text { Lourenço and Katz [18]; Ribeiro } \\
\text { et al. [34]; and Brandão and } \\
\text { Arbage [19] }\end{array}$ \\
\hline $\begin{array}{c}\text { Proper handling care when } \\
\text { handling food }\end{array}$ & All stages & $\begin{array}{l}\text { Ribeiro et al. [34]; Almeida et al. } \\
\text { [24]; Tofanelli et al. [23]; } \\
\text { Fagundes et al. [21]; Belik et al. } \\
\text { [20]; Lourenço and Katz [18]; } \\
\text { Buzby and Hyman [35] }\end{array}$ \\
\hline Proper packaging & $\begin{array}{l}\text { Transport, storage, } \\
\text { warehousing, } \\
\text { commercialization }\end{array}$ & $\begin{array}{c}\text { Almeida et al. [24]; Ceccato and } \\
\text { Basso [32]; Fagundes et al. [21]; } \\
\text { Garrone, Melacini and Perego } \\
\text { [36]; Halloran et al. [37] }\end{array}$ \\
\hline $\begin{array}{c}\text { Packaging (standard and } \\
\text { organized in } \\
\text { packages, boxes) }\end{array}$ & $\begin{array}{l}\text { Transport, storage, } \\
\text { warehousing, } \\
\text { commercialization }\end{array}$ & $\begin{array}{l}\text { Almeida et al. [24]; Ceccato and } \\
\text { Basso [32]; Ribeiro et al. [34]; } \\
\text { Tofanelli et al. [23]; Fagundes et al. } \\
\text { [21]; Lourenço and Katz [18]; } \\
\text { Tofanelli et al. [34] }\end{array}$ \\
\hline
\end{tabular}


Table 1. Cont.

\begin{tabular}{|c|c|c|}
\hline Best Practices & Stage & Authors \\
\hline $\begin{array}{l}\text { Improvement in structure } \\
\text { and facilities (refrigerated } \\
\text { shelves and chambers) }\end{array}$ & $\begin{array}{l}\text { Transport, storage, } \\
\text { warehousing, } \\
\text { commercialization }\end{array}$ & $\begin{array}{l}\text { Almeida et al. [24]; Ribeiro et al. } \\
\text { [34]; Ceccato and Basso [32]; } \\
\text { Fagundes et al. [21]; Tofanelli et al. } \\
\text { [23]; Tofanelli et al. [34]; Lourenço } \\
\text { and Katz [18]; Questedet al. [38]; } \\
\text { Scholz et al. [13] }\end{array}$ \\
\hline $\begin{array}{l}\text { Demand forecasting } \\
\text { (demand pulled) and } \\
\text { inventory control }\end{array}$ & $\begin{array}{l}\text { Planting, storage, } \\
\text { warehousing, } \\
\text { commercialization }\end{array}$ & $\begin{array}{l}\text { Ceccato and Basso [32]; Almeida } \\
\text { et al. [24], Tofanelli et al. [23]; } \\
\text { Tofanelli et al. [34]; Brandão and } \\
\text { Arbage [19]; Prado et al. [39]; } \\
\text { Buzby and Hyman [35]; } \\
\text { Papargyropoulou et al. [39]; } \\
\text { Stefan et al. [40]; Garrone et al. } \\
\text { [36]; Betz et al. [41]; Sonnino and } \\
\text { McWilliam [42] }\end{array}$ \\
\hline $\begin{array}{c}\text { Decrease in retail and } \\
\text { wholesale prices and other } \\
\text { quick selling actions }\end{array}$ & Commercialization & $\begin{array}{l}\text { Tofanelli et al. [33]; Prado et al. } \\
\text { [22]; Tofanelli et al. [23] }\end{array}$ \\
\hline $\begin{array}{l}\text { Integrated logistics and } \\
\text { SCM (supplier selection, } \\
\text { partnerships, } \\
\text { information sharing) }\end{array}$ & All stages & $\begin{array}{c}\text { Brandão and Arbage [19]; } \\
\text { Tofanelli et al. [23]; Tofanelli et al. } \\
\text { [34]; Ceccato and Basso (2012); } \\
\text { Lourenço and Katz [18]; Buzby } \\
\text { and Hyman [35]; } \\
\text { Papargyropoulou et al. [39]; } \\
\text { Stefan et al. [40]; Garrone et al. } \\
\text { [36]; Betz et al. [41]; Sonnino and } \\
\text { McWilliam [42]; } \\
\text { Aschemann-Witzel et al. [43] }\end{array}$ \\
\hline $\begin{array}{l}\text { Regional Fruit Purchase } \\
\text { (nearest suppliers) }\end{array}$ & Commercialization & $\begin{array}{l}\text { Almeida et al. [24]; Ceccato and } \\
\text { Basso [32]; Tofanelli et al. [33] }\end{array}$ \\
\hline $\begin{array}{l}\text { Guidance and training } \\
\text { of labor }\end{array}$ & All stages & $\begin{array}{c}\text { Almeida et al. [24]; Lourenço and } \\
\text { Katz [18], Ceccato and Basso [32]; } \\
\text { Tofanelli et al. [33]; } \\
\text { Fagundes et al. [21] }\end{array}$ \\
\hline $\begin{array}{l}\text { Adoption of processes and } \\
\text { processing technology }\end{array}$ & Processing & $\begin{array}{c}\text { Marchetto et al. [44]; Prado et al. } \\
\text { [22]; Tofanelli et al. [23]; } \\
\text { Tofanelli et al. [34] }\end{array}$ \\
\hline $\begin{array}{l}\text { Appropriate vehicle and } \\
\text { improved road conservation }\end{array}$ & Transport & $\begin{array}{l}\text { Almeida et al. [24]; Ribeiro et al. } \\
\text { [34]; Tofanelli et al. [33]; Fagundes } \\
\text { et al. [21]; Lourenço and Katz [18]; } \\
\text { Ceccato and Basso [32] }\end{array}$ \\
\hline $\begin{array}{c}\text { Stacking, receiving } \\
\text { (inspection and checking), } \\
\text { and handling } \\
\text { (cargo equipment) }\end{array}$ & $\begin{array}{l}\text { Transport, storage, } \\
\text { warehousing, } \\
\text { commercialization }\end{array}$ & $\begin{array}{l}\text { Almeida et al. [24]; Lourenço and } \\
\text { Katz [18]; Ceccato and Basso [32]; } \\
\text { Brandão and Arbage [19]; Prado } \\
\text { et al. [22]; Fagundes et al. [21]; } \\
\text { Tofanelli et al. [23]; } \\
\text { Tofanelli et al. [34] }\end{array}$ \\
\hline $\begin{array}{l}\text { Maintenance and hygiene of } \\
\text { packaging, transport, store, } \\
\text { and warehouse }\end{array}$ & $\begin{array}{l}\text { Transport, storage, } \\
\text { warehousing, } \\
\text { commercialization }\end{array}$ & $\begin{array}{l}\text { Almeida et al. [24]; Ceccato and } \\
\text { Basso [32] }\end{array}$ \\
\hline
\end{tabular}


Table 1. Cont.

\begin{tabular}{ccc}
\hline Best Practices & Stage & Authors \\
\hline $\begin{array}{c}\text { Education and awareness of } \\
\text { the final consumer } \\
\text { (manipulation campaigns) }\end{array}$ & Commercialization & Tofanelli et al. [33]; Prado et al. \\
& [22]; Aschemann-Witzel et al. [43]; & Byker et al. [14], Stefan et al. [40]; \\
& Stancu et al. [11]; Secondi et al. \\
& [13]; Parizeau et al. [17]; \\
Visschers et al. [12]
\end{tabular}

According to Table 1, among the best practices can be highlighted the concerns to improve the quality of food, the extra care to handle fruits and vegetables, the proper packaging and facilities, such as structures with refrigerated chambers and shelves, management of the quantity offered, the information sharing and collaborative partnerships, and the education and awareness of the final consumer.

The main logistical actions to reduce food waste due to deterioration are purchase planning, storing products in air-conditioned environments, appropriate boxes and packaging, correctly exposing products, conducting campaigns with customers to properly handle products, acclimatizing the store, and regulating the store refrigerators and freezers [22]. The authors also proposed actions to avoid losses due to packaging damage: care in unloading and handling products, improving storage, training employees, and reinforcing care in the proper display of products. Some internal and external measures to reduce vegetable losses were pointed out by Tofanelli et al. [23]. The internal ones: improving inventory control, purchase of fresh vegetables, purchase of regional vegetables, decrease in retail prices, care in handling during transportation, prevention of excessive handling by the consumer, and improving the structure of the establishment. The external ones: lower wholesale prices, closer wholesale suppliers, educating the final consumer, enhancing the quality of vegetables, improving packaging, encouraging local vegetable growing, and greater integration and collaboration of members of the agricultural supply chain.

The measures to reduce food waste are cleaning transport, monoblock boxes, and marketing benches; uniformity in the organization of vegetables in boxes; selecting the best times for the outlets; and product offers according to demand [24].

The great majority of studies aim to understand the behavior of the final consumer, listing the factors that drive food waste, considering that some studies point out that, at the consumption stage, there is more generation of food waste and a greater possibility of prevention [11]. However, although consumers appear to make the most significant contribution to the wasted food volume, there is almost no information on the drivers of such behavior in consumer households [40]. In this sense, the minimization of food residues in developed countries should be focused on the retail and consumption stages [39]. The waste of consumer-related food is a complex issue requiring collaboration among various actors in the supply chain and actions to increase awareness [43].

\section{Research Techniques}

This research is characterized as applied, descriptive, and exploratory and uses a qualitative approach. We conducted a systematic literature review and a multiple case study. Table 2 shows the technical procedures adopted and their respective research instruments to collect data. The study was divided into two stages and related technical procedures. The first phase covered two systematic literature reviews, and the second one the multiple case study. 
Table 2. Relation between technical procedures and data collection instruments.

\begin{tabular}{cccc}
\hline & Procedure & Data Collection Instrument & Source \\
\hline \multirow{2}{*}{ 1st phase } & $\begin{array}{c}\text { Systematic literature review } \\
\text { (Brazilian literature) }\end{array}$ & Documental analysis & Cronin et al. [45] \\
\cline { 2 - 4 } & $\begin{array}{c}\text { Systematic literature review } \\
\text { (international literature) }\end{array}$ & Documental analysis & Pagani et al. [46] \\
\hline $\begin{array}{c}\text { 2nd } \\
\text { phase }\end{array}$ & Case study (multiple cases) & $\begin{array}{c}\text { Semi-structured interviews } \\
\text { and direct observation }\end{array}$ & Yin [47] \\
\hline
\end{tabular}

We carried out two systematic literature reviews to demonstrate state of the art on food losses and waste. In addition to summarizing the main problems throughout the agrifood supply chain, the review pointed out solutions through the implementation of best practices. Two different protocols were used to carry out the systematic literature reviews: (i) the Brazilian one used the protocol from Cronin et al. [45] and (ii) the international one used the protocol from Pagani et al. [46]. Two procedures were necessary considering that the Brazilian journals, at most, do not have impact factor information, which would be required to calculate the InOrdinatio Index proposed by Pagani et al. [46]. Thus, the protocol from Cronin et al. [45] was used. To summarize, the first three steps were the same in both protocols; they differed in terms of the filtering process, because the Methodi Ordination uses the InOrdination as an additional step of filtering.

The Brazilian literature analysis followed the protocol of Cronin et al. [45], with the following steps: (a) research question formulation; (b) set of inclusion and exclusion criteria; (c) selection and access to literature; (d) quality evaluation of the literature included in the review; and (e) result analysis, synthesis, and dissemination. From the keywords food waste OR food losses, in the Portuguese language, 15,100 results were found on the Google academics platform in order of relevance. The titles and keywords of the first 400 links were selected and evaluated. Due to the filtering process, 78 were eliminated. In addition, 310 were excluded due to inconsistency with the scope of the study. After reading the abstracts, 12 articles were thoroughly analyzed.

In the systematic international review, the Methodi InOrdinatio was used to classify the quality of the articles [46]. The method allowed us to select the best articles by ordering the highest scores. The calculation considers the publication year, the impact factor of the journal, and the number of citations. Pagani et al. [46] advise the researcher to determine the cutoff line so that only the articles above the line are read in full. Thus, 17 articles were selected, which presented an InOrdinatio superior to 123. At first, 437 articles were found, considering the same keywords in the English language. The studies were analyzed by reading the titles and abstracts. Of the 437 articles, 358 were excluded due to inconsistency with the theme. The remaining 79 articles passed through the Methodi Ordinatio filter, which calculates an index called InOrdinatio to rank the papers considering the number of citations, year of publication, and impact factor, leaving, in the end, 17 articles higher than the cutoff line of 123 points of InOrdinatio. Thus, the final systematic review included 29 articles -12 Brazilian and 17 international papers. Figure 1 presents the results of the two SLRs. It is important to emphasize that this procedure supported the questionnaire elaboration applied with the sample of participants of the study. 


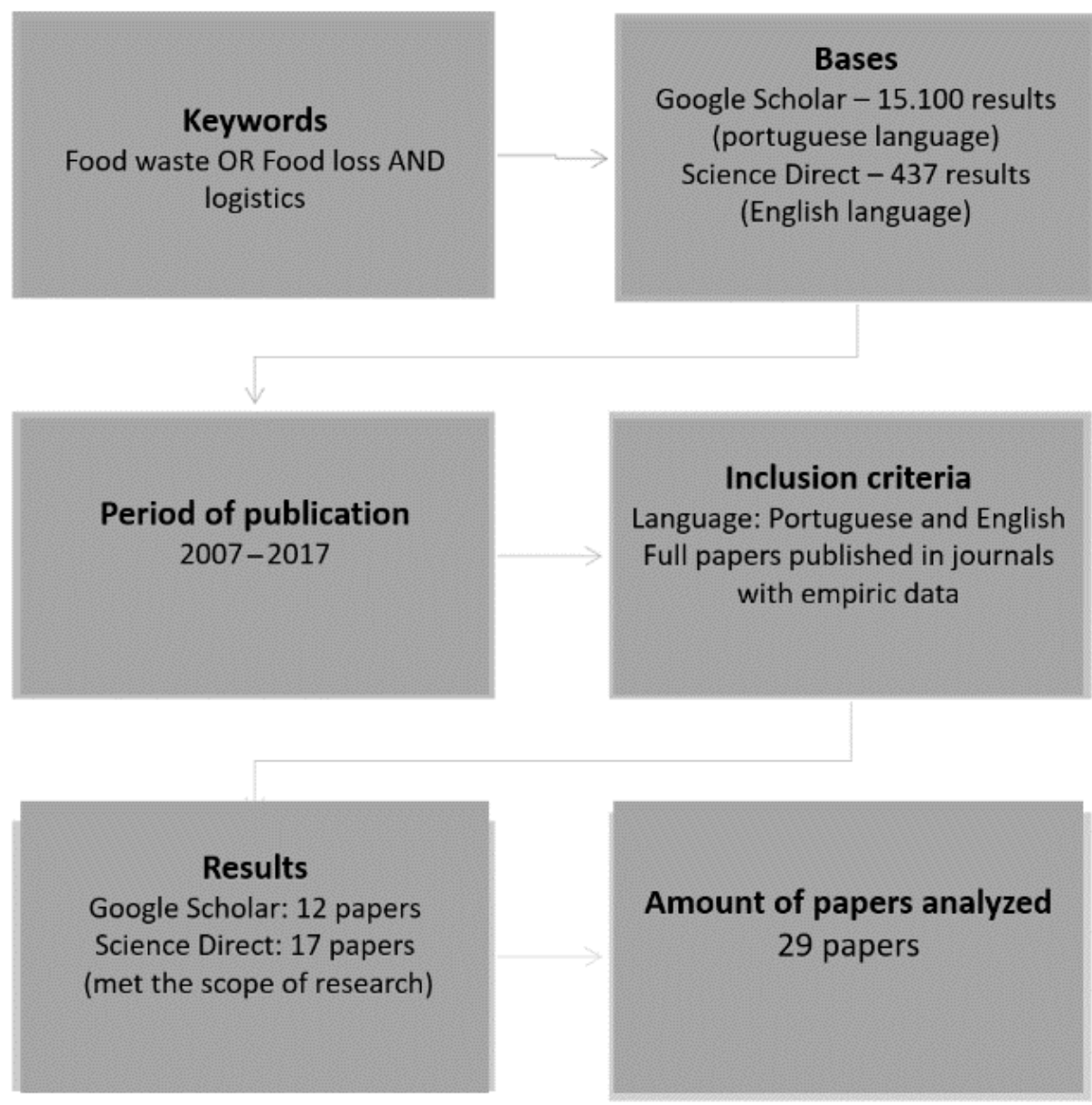

Figure 1. Protocol to select and filter papers analyzed in the SLR.

For this reason, the SLR considered just papers published until 2017. We understand that this is a limitation of this study. Further studies can confirm the logistic practices from 2018 to the future.

Regarding the second phase of the research, the study of multiple cases was carried out mainly through semi-structured interviews and by the direct observation "in loco" in the stores of fruits and vegetables located in the Federal District and wholesaler storages, with the professionals responsible for the fruit and vegetable commercialization (owners and managers), involving retailers and wholesalers in the Federal District, Brazil. The study was carried out at Ceasa/DF, the center of food distribution (wholesale) and local retailers, located in the following administrative regions of the Federal District: Samambaia, Taguatinga, Ceilândia, Guará, and Asa Norte. The interviews were conducted in person, at the establishments, without an appointment by occasional visits, with an average duration of $25 \mathrm{~min}$. The interviews were carried out from 2019 to 2020 and recorded with the authorization of the interviewees to allow the transcription for further interpretation and analysis.

Nineteen fruit and vegetable retailers and eight wholesalers from the CEASA-DF were part of this analysis. It is noted that a sample was not established a priori, being followed by the theoretical saturation technique. Regarding the size of wholesale establishments, $37.5 \%$ were large companies, and the remainder were small ones. Of the retailers surveyed, $16 \%$ were individual microentrepreneurs, $53 \%$ were microenterprises, $21 \%$ were small, and $10 \%$ represented large companies. Regarding the profile of the interviewees, $53 \%$ were the owners of the establishments, $26 \%$ were managers, $16 \%$ were replenishment managers and, $5 \%$ were sales managers. Table 3 shows the characteristics of the study participants. 
Table 3. Characterization of participants of the study.

\begin{tabular}{|c|c|c|c|c|c|c|c|}
\hline Id & $\begin{array}{l}\text { Place } \\
\text { (AR) }\end{array}$ & $\begin{array}{c}\text { Size of } \\
\text { Company }\end{array}$ & Participant & Id & $\begin{array}{l}\text { Place } \\
\text { (AR) }\end{array}$ & Size & Participant \\
\hline E1 & Samambaia & Micro & Owner & E11 & Ceilândia & Micro & Owner \\
\hline E2 & Samambaia & Micro & Owner & E12 & Guará & Micro & $\begin{array}{l}\text { General } \\
\text { manager }\end{array}$ \\
\hline E3 & Samambaia & $\begin{array}{l}\text { Individual } \\
\text { microentre- } \\
\text { preneur }\end{array}$ & Owner & E13 & Guará & Micro & Owner \\
\hline $\mathrm{E} 4$ & Samambaia & Micro & Owner & E14 & Guará & Micro & $\begin{array}{l}\text { Replenishment } \\
\text { manager }\end{array}$ \\
\hline E5 & Samambaia & Small & $\begin{array}{l}\text { General } \\
\text { Manager }\end{array}$ & E15 & Guará & Larger & $\begin{array}{l}\text { Replenishment } \\
\text { manager }\end{array}$ \\
\hline E6 & Taguatinga & Small & $\begin{array}{l}\text { General } \\
\text { Manager }\end{array}$ & E16 & Guará & Micro & Owner \\
\hline E7 & Taguatinga & Micro & $\begin{array}{l}\text { General } \\
\text { Manager }\end{array}$ & E17 & $\begin{array}{l}\text { Asa } \\
\text { Norte }\end{array}$ & Micro & $\begin{array}{l}\text { Replenishment } \\
\text { manager }\end{array}$ \\
\hline E8 & Taguatinga & $\begin{array}{l}\text { Individual } \\
\text { microentre- } \\
\text { preneur }\end{array}$ & Owner & E18 & $\begin{array}{l}\text { Asa } \\
\text { Norte }\end{array}$ & Larger & Supply manager \\
\hline E9 & Taguatinga & $\begin{array}{l}\text { Individual } \\
\text { microentre- } \\
\text { preneur }\end{array}$ & Owner & \multirow[t]{2}{*}{ E19 } & \multirow{2}{*}{$\begin{array}{l}\text { Asa } \\
\text { Norte }\end{array}$} & \multirow[t]{2}{*}{ Small } & \multirow[t]{2}{*}{ Owner } \\
\hline E10 & Ceilância & Small & $\begin{array}{l}\text { Sales } \\
\text { manager }\end{array}$ & & & & \\
\hline
\end{tabular}

According to Table 3, 19 companies were part of this analysis, representing the retail sector of fruits and vegetables, $26 \%$ located in Samambaia, $21 \%$ in Taguatinga, $11 \%$ in Ceilândia, 27\% in Guará, and 15\% in Asa Norte. The companies were found in searches conducted on the Google Maps tool, based on the search for keywords in Portuguese: "Verdurão," "sacolão," "frutaria," and "Hortifruti," which are terms used to refer to retailers specialized in fruits and vegetables in Brazil. Thirty-six establishments were found, of which six were no longer in operation, four did not accept to participate in the study, and the other seven were not accessible-four due to their location and the remaining three because they belong to foreigners who are not able to communicate in Portuguesepreventing the conduction of the interviews. Therefore, the choice of the participating companies followed the criteria of accessibility (the managers/owners should agree to participate) and representativeness (the companies should meet the search criteria).

A semi-structured interview script, designed on the basis of the systematic literature reviews, was used for data collection. The script went through analysis by judges to give more robustness to the items. The judges were seven teachers with an affinity to the themes of logistics and agribusiness. The questions were analyzed for the criteria of intelligibility, clarity of information, and coherence of terms, considering the pre-established objectives. The script was composed of four categories: Handling; Conservation and Maintenance; Control and Logistics Management, and Awareness. In total, 23 questions were added, with six items on the first category, seven items on the second category, nine items on the third category, and one item on category 4.

We conducted a thematic categorial content analysis technique to analyze the results, following the protocol proposed by Bardin [48]: pre-analysis; exploration of the material; and treatment of the results, inference, and interpretation. We detailed the results in categories that are analyzed under the thematic content of the interviews and documental analysis, enabling the identification of the meaning in the interview composition. The categories established a priori were as follows: (a) handling, (b) conservation and maintenance, (c) control and logistical management, (d) awareness. 


\section{Results and Discussion}

Table 4 presents the main obtained results from interviews and direct observation for the categories handling, conservation, management and control, and awareness for the local retailers and wholesalers of fruits and vegetables considered in this study.

Table 4. Main results of the case studies.

\begin{tabular}{|c|c|c|c|}
\hline Category & Main Results & Retailer & Wholesaler \\
\hline \multirow{7}{*}{ Handling } & $\begin{array}{l}\text { The loads originate primarily from the } \\
\text { Northeast and Southeast regions }\end{array}$ & & $x$ \\
\hline & $\begin{array}{l}\text { Manual or trolley unloading makes work } \\
\text { easier and reducing impact injuries }\end{array}$ & $X$ & $X$ \\
\hline & $\begin{array}{l}\text { The conference of loads, regarding quantity } \\
\text { (weight), quality (uniformity, maturation, } \\
\text { presence of imperfections) }\end{array}$ & $x$ & $x$ \\
\hline & $\begin{array}{c}\text { The storage process involves stacking and } \\
\text { removing excess merchandise from } \\
\text { the edges }\end{array}$ & $x$ & \\
\hline & High waste due to consumer handling & $x$ & \\
\hline & $\begin{array}{l}\text { Consumers are well advised on the } \\
\text { correct handling }\end{array}$ & & $x$ \\
\hline & $\begin{array}{l}\text { The most significant waste due to handling } \\
\text { comes from the consumer squeezing and } \\
\text { kneading the fruits and vegetables }\end{array}$ & $x$ & \\
\hline \multirow{9}{*}{ Conservation } & $\begin{array}{l}\text { There are cold chambers for the fruit and } \\
\text { vegetable storage which, prolongs } \\
\text { durability and reduces waste }\end{array}$ & & $x$ \\
\hline & $\begin{array}{l}\text { The durability of items that are refrigerated } \\
\text { is noticeably increased, reducing waste }\end{array}$ & $x$ & $x$ \\
\hline & $\begin{array}{l}\text { The use of packaging in the } \\
\text { commercialization environment preserves } \\
\text { and protects the food }\end{array}$ & $x$ & \\
\hline & $\begin{array}{c}\text { The conservation of fruits and vegetables in } \\
\text { transport requires the use of correct } \\
\text { packaging to prevent abrasion }\end{array}$ & & $x$ \\
\hline & $\begin{array}{l}\text { The fleet used to transport cargo is varied } \\
\text { and not refrigerated in most establishments }\end{array}$ & $x$ & $x$ \\
\hline & $\begin{array}{l}\text { CEASA requires the use of correct material } \\
\text { for packaging and transportation: } \\
\text { plastic boxes }\end{array}$ & & $x$ \\
\hline & $\begin{array}{l}\text { Hygienization and pest control have an } \\
\text { impact on the durability of FVLs about the } \\
\text { removal of insects }\end{array}$ & $x$ & $x$ \\
\hline & $\begin{array}{l}\text { Damaged products are removed to avoid } \\
\text { the degrading agents from spreading }\end{array}$ & $x$ & \\
\hline & $\begin{array}{l}\text { The use of damaged and imperfect products } \\
\text { occurs through processing for } \\
\text { internal consumption }\end{array}$ & $x$ & \\
\hline
\end{tabular}


Table 4. Cont.

\begin{tabular}{|c|c|c|c|}
\hline Category & Main Results & Retailer & Wholesaler \\
\hline \multirow{13}{*}{$\begin{array}{l}\text { Management } \\
\text { and control }\end{array}$} & Absence of purchase planning & $X$ & $X$ \\
\hline & Excessive purchases generate waste & & $x$ \\
\hline & $\begin{array}{l}\text { The cost spent, the time dedicated, and the } \\
\text { refusal of the owner appear as an obstacle to } \\
\text { the adoption of inventory } \\
\text { management tools }\end{array}$ & $x$ & $x$ \\
\hline & $\begin{array}{c}\text { Strategies to increase turnover revolve } \\
\text { around high-end offers, a single-price offer, } \\
\text { and the establishment of a day to } \\
\text { promote FVLs }\end{array}$ & $x$ & \\
\hline & $\begin{array}{l}\text { Strategies for selling imperfect items revolve } \\
\text { around negotiation with suppliers, selling to } \\
\text { regions with lower purchasing power, and } \\
\text { selling to establishments that process FVLs }\end{array}$ & & $x$ \\
\hline & $\begin{array}{l}\text { There are no measures to reduce the } \\
\text { distance between retail and } \\
\text { wholesale/wholesale and producer }\end{array}$ & $x$ & $x$ \\
\hline & $\begin{array}{l}\text { Information about demand forecasting } \\
\text { takes place in a short period, not providing } \\
\text { other members with a planning option }\end{array}$ & $x$ & $x$ \\
\hline & $\begin{array}{l}\text { Waste reduction is achieved through } \\
\text { donations made to needy individuals } \\
\text { and institutions }\end{array}$ & $x$ & $x$ \\
\hline & $\begin{array}{l}\text { The difficulty in donating food is related to } \\
\text { the cost of transport to the beneficiary }\end{array}$ & $x$ & \\
\hline & A solid-waste company does disposal & $x$ & $x$ \\
\hline & $\begin{array}{l}\text { Disposal is done in the common garbage for } \\
\text { collection by the urban cleaning service }\end{array}$ & $x$ & \\
\hline & $\begin{array}{l}\text { Farm owners collect food residues for } \\
\text { animal feed and soil fertilization }\end{array}$ & $x$ & \\
\hline & $\begin{array}{c}\text { Lack of training for employees and } \\
\text { awareness of owners about the problem } \\
\text { of waste }\end{array}$ & $x$ & $x$ \\
\hline Awareness & $\begin{array}{l}\text { It has campaigns or information about } \\
\text { education and awareness of the final } \\
\text { consumer regarding the correct handling } \\
\text { and domestic planning }\end{array}$ & & \\
\hline
\end{tabular}

The handling category identified the receiving, storage, warehouse, and commercialization practices (Table 4). As soon as the trucks arrive at the retail establishment, manual unloading or unloading with the aid of trolleys and pallet trucks is made, which facilitates handling work and reduces injuries due to impact, upon receiving the cargo, checking what is being received stands out regarding the quantity (weight) and the products' quality (uniformity, degree of maturation, and presentation of injuries or imperfections). The storage and warehousing processes involve stacking the boxes, removing at first the excess of goods at the edges of the boxes.

In $40 \%$ of the establishments that have storage for the fruits and vegetables, there are no cold rooms to store them, which reduces their durability. All establishments reported having significant waste due to excessive and incorrect handling by the final consumer (e.g., kneading and squeezing food). However, $27 \%$ of establishments did not advise consumers on the correct handling of fruits and vegetables to avoid embarrassment. 
The conservation category identified the practices of conservation, maintenance/hygiene, organization, and separation of food. The increase in durability and the preservation of the quality of the exposed items under refrigeration stood out, which considerably reduces waste. The use of packaging is essential for the conservation of fruits and vegetables, which suffer effects related to the transport itself and the sales environment, and the effects of excessive handling. In turn, sanitation impacts the durability of fruits and vegetables concerning the removal of insects.

The shelves' organization is relevant in terms of separation by type and group of products. Damaged fruits and vegetables are removed when the shelf is replenished and throughout the day to avoid the spread of degrading agents. Products considered imperfect, outside the aesthetic standards required by customers, are removed from the shelves or are not exposed. Then, they are directed to the employees' consumers, avoiding waste-some establishments process these imperfect products for sale as fruit pulps, soup preparations, fruit salad, and natural juices.

The management and control category identified practices related to demand forecasting and the use of inventory management tools, a strategy to increase product turnover, and measures to reduce the distance between retail and supplier, in addition to the reverse logistics of waste and imperfect food. The results showed the absence of purchase planning and predictions made through notes and lists without strategic planning to reduce waste. Excessive purchases generated waste of fruits and vegetables even for establishments that make daily purchases. It was noted that the adoption of information technology tools for the planning of purchases did not occur due to the cost, the spent time, and the owner's refusal.

The strategies to increase the product turnover revolved around promotions (for example, Green Tuesday and Green Wednesday) and the offer of a single price, the socalled sacolão. The practice of sacolão has become unfeasible due to price discrepancies and the variety of products offered. We observed that there was little exchange of information between retailers and wholesalers about the demand forecast. As a result, the wholesaler's planning was also affected. Negotiation with suppliers of items with minor imperfections was a possibility given waste mitigation strategies. The reduction of waste also occurred through the use of foods that were still within the expected nutritional level but were no longer considered within the standards of retail marketing because they contained some imperfection or are damaged in some parts.

Regarding the possibility of food donation, there was difficulty due to the cost of transporting the products to the entity to be benefited. Food unfit for human consumption was used for animal feed or compost production or was discarded in the garbage for collection by the urban cleaning service. Regarding the awareness category, none of the retail establishments had awareness campaigns for the final consumer. The impediments revolved around the costs and spent time. Moreover, retailers pointed out that they had never been approached by the private sector or government institutions for presentation and incentives for initiatives in this regard.

Regarding the study carried out with wholesalers, three categories were established. The first was about handling the receiving, storage, and marketing stages. The results show that about $50 \%$ of the food sold came from the northeast and southeast regions of the country, $25 \%$ from the south, and $12.5 \%$ from the central-west region. In companies that work with imported products, about $12.5 \%$ came from Argentina and Chile. Regarding the unloading process of the trucks, the loads were received, weighed, and taken into the box. During the receipt of the products, the employees responsible for checking the loads evaluated the temperature, uniformity, degree of maturity, and quality of the received food. Regarding batch uniformity, fruit sizes were checked, standardization was always prioritized, and the most presentable items were separated from imperfect ones. The cold chambers located inside the box were used so that the fruits were packaged and had prolonged durability and a visible reduction of waste. 
The second category was the conservation, maintenance/hygiene, and separation of damaged or imperfect items. In terms of conservation in the commercial environment, we highlight the establishments that used cold rooms. It is noteworthy that CEASA stipulates that permit holders use correct packaging without using wooden boxes. However, the use of these is still being verified. The issue of transporting cargo over long distances was one of the factors to be analyzed since conservation requires refrigerated box trucks. However, the fleet varied widely between open bodies, closed box trucks, and refrigerated box trucks.

Regarding the maintenance and hygiene of the commercialization environments, the licensees cleaned the box and washed the containers frequently. Regarding the use of insecticides for the removal of insects, the licensees informed us that CEASA was responsible for environmental pest control. Concerning removing damaged or imperfect products, the interviewees aimed to remove damaged products and discard them so that they did not damage the cargo. For defective items, just as in retail, price offers were the first choice. Another mentioned option was sale to establishments that would process this food, such as snack bars and restaurants.

Furthermore, the third category referred to demand forecasting and the use of inventory management tools, a strategy to increase product turnover, the relationship between retail and supplier, and CEASA's role in terms of waste and reverse logistic waste and imperfect food. Wholesalers who used a management system that assisted in planning the purchase had difficulty interpreting the information. This highlights the importance of training and development of employees, not only regarding correct handling but also with respect to feeding information systems. It should be noted that the large stocks held were responsible for a large part of the waste at the supply terminals. To increase the turnover of products, the sale of products to the "sacolão" was pointed out, the negotiation of a lower price with the producer, the search for customers and the guarantee that they work with a quality product.

It was noticed that the wholesaler link, the permit holders of CEASA-DF, usually exchanged price information and the quality of the products with the producer. The information exchanged between retail and wholesale revolved around the requirements of retailers concerning quality, price, delivery time, and merchandise exchanges. There was no sharing of strategic information among members about forecasting demand or stock level to reduce waste. Respondents pointed to the zero-waste program as the initiative to reduce waste. In addition to sending damaged and imperfect food to CEASA-Federal District's zero-waste program, respondents reported making donations to entities such as daycare centers, churches, non-governmental organizations (NGOs), and SESC (Social Service of Commerce). There was no waste reuse program for composting or producing animal feed. There was still much waste at CEASA-DF due to the lack of awareness and involvement of permit holders in waste reduction practices. Some studies deal with solutions to improve food donations from restaurants to the food-insecure population using modeling [49], which can be pointed out as a positive effort involving the storage, collection, and transportation logistical activities to reduce food waste.

\section{Conclusions}

This study dealt with the analysis of good logistical practices in reducing fruit and vegetable waste in retail and wholesale companies, as these marketing links comprise stages in the supply chain with a high percentage of waste. To provide a broad and diversified panorama and to get inputs for the elaboration of the questionnaires to collect data, a systematic national and international review was carried out, which supported the item's construction of the semi-structured script used in the interviews in the study of multiple cases, which is the central part of this study.

Given the obtained results, the need to make consumers aware of the correct handling of fruits and vegetables in retail establishments is highlighted. In addition, we emphasize the requirement for the companies to carry out campaigns with public-private partnerships to educate the consumer, either in terms of purchase planning as in the full use of food. 
Regarding the wastes that still occur in CEASA-DF, measures to raise the awareness and involvement of permit holders must be adopted, as well as the development of facilities for processing the fruit and vegetables that end up being discarded in containers and destined for landfills.

The research has several contributions. Academically, considering the importance of studying the proposed theme in depth, the research contributes to a more significant discussion about food waste and the investigation of the phenomenon in the retail and wholesale environment. Specifically, the research contributed to the panorama of the national and international state of the art about the good practices carried out along the agricultural supply chain. Furthermore, the logistical practices adopted by two links in the agri-food chain, retailers and wholesalers, were identified to reduce food waste.

From a managerial point of view, the study contributes to retail establishments creating employees and consumers awareness campaigns as to the problems caused by excessive and inadequate handling in the receiving, storage, and marketing stages, contributing to the structuring of marketing processes. As well as in identifying the variables necessary for the maintenance and conservation of fruits and vegetables concerning investment in refrigerated facilities and structures. Our study highlights the relevance of the partnership of retail and wholesale companies with associations that aim at waste reduction. From contributions to the public policy formation, this research points out flaws in the integrated management of the chain, about the adoption of collaborative partnership relationships, information sharing, and lasting partnerships. It leads to several opportunities for creating policies that aim to educate the end consumer about proper handling, planning domestic consumption, making full use of food and conservation, and creating tax incentives to expand the cold chain along the production chain for perishable foods. In general, we expect that this research's results will encourage the adoption of good practices that reduce food waste as a whole minimizing economic, social, and environmental impacts.

Furthermore, we should point out some limitations of the research. The first was the failure to use the same protocol for selecting and filtering papers in the national and international systematic literature reviews. The Methodi Ordinatio, proposed by Pagani et al. [46], was used only in the international review since national journals did not have the impact factor. Regarding the empirical phase of the research, related to case studies, the type of retailer studied was limited to grocery stores and fruit shops. The type of food studied covered only the category of fruits and vegetables, which excludes all the other types of food waste. We also considered the food waste generated in the logistics processes and not that after consumption.

Considering the limitations, some suggestions for future research are proposed. The first is to conduct a more comprehensive systematic literature review, following a harmonized protocol. It would also be interesting to study food waste in other retail links, such as supermarkets of different sizes, restaurants, and after the consumption phase. Further studies can focus on other types of food waste, such as non-perishable and industrialized foods. Additionally, future studies may cover the entire agri-food supply chain, including the logistics processes occurring in the suppliers and the production, the waste in the consumption stage, and the final consumers' role.

Further studies can approach the modeling approach from operational research to propose, for example, a volunteer-based crowd-shipping program for food rescue, considering the restaurant's food donation delivery as proposed by Mittal et al. [49]. Similar modeling can be conducted in the case of wholesaler donations. In addition to that, other models can use modeling from the multicriteria decision aid approach to optimize food donation, helping food-insecure people.

Author Contributions: Conceptualization, P.G. and R.C.C.d.A.; Methodology, P.G. and R.C.C.d.A.; Formal Analysis, P.G. and R.C.C.d.A.; Investigation, P.G. and R.C.C.d.A.; Writing-Original Draft Preparation, P.G., K.M.T. and E.A.d.M.W.; Writing-Review \& Editing, P.G., K.M.T. and E.A.d.M.W.; Visualization, P.G., K.M.T. and E.A.d.M.W.; Supervision, P.G. All authors have read and agreed to the published version of the manuscript. 
Funding: This research received no external funding.

Institutional Review Board Statement: Not applicable.

Informed Consent Statement: Not applicable.

Acknowledgments: We acknowledge the Brazilian Council for the Improvement of Higher Education (CAPES) for its support.

Conflicts of Interest: The authors declare no conflict of interest.

\section{References}

1. FAO. Food Wastage Footprint. 2018. Available online: http://www.fao.org/nr/sustainability/food-loss-and-waste/en/ (accessed on 9 April 2021).

2. Food and Agriculture Organization of the United Nations-FAO. Global Initiative on Food Loss and Waste Reduction. 2015. Available online: http:/ / www.fao.org/3/a-i4068e.pdf (accessed on 14 April 2021).

3. EMBRAPA. Frutas e Hortaliças. s.d. Available online: https://www.embrapa.br/grandes-contribuicoes-para-a-agriculturabrasileira/frutas-e-hortalicas (accessed on 10 June 2021).

4. Philereno, D.C.; Dalegrave, J. O desperdício de alimentos: Um estudo de caso na CEASA Serra RS. Estudo Debate 2017, 24, 7-25. [CrossRef]

5. World Resources Institute. Reducing Food Loss and Waste: Creating a Sustainable Food Future, Installment Two (Working Paper). 2018. Available online: https://wriorg.s3.amazonaws.com/s3fs-public/reducing_food_loss_and_waste.pdf (accessed on 9 April 2021).

6. FAO. Perdas e Desperdícios de Alimentos na América Latina e no Caribe. 2018. Available online: http://www.fao.org/americas / noticias/ver/pt/c/239394/ (accessed on 12 May 2021).

7. Parlinska, M.; Pagare, A. Food Losses and Food Waste Versus Circular Economy. Probl. World Agric./Probl. Rol. Swiat. 2018, 18, 228-237. [CrossRef]

8. Laisney, C.; Soyeux, A.; Redlingshöfer, B. Les Gaspillages et les Pertes de la «Fourche à la Fourchette» Production, Distribution, Consommation. Document de Travail du Centre D'études et Prospective. 2013. Available online: https:/ /agriculture.gouv.fr/lesgaspillages-et-les-pertes-de-la-fourche-la-fourchette-document-de-travail-ndeg7 (accessed on 9 April 2021).

9. Parfitt, J.; Barthel, M.; Macnaughton, S. Food Waste within Food Supply Chains: Quantification and Potential for Change to 2050. Philos. Trans. R. Soc. 2010, 365, 3065-3081. [CrossRef]

10. Comissão Nacional de Combate ao Desperdício Alimentar-CNCDA. Combater o Desperdício Alimentar: Uma Responsabilidade do Produtor ao Consumidor. 2017. Available online: https://www.cncda.gov.pt/images/Resultados/ RelatorioProgressoCNCDA31mar2017.pdf (accessed on 24 April 2021).

11. Stancu, V.; Haugaard, P.; Lähteenmäki, L. Determinants of consumer food waste behaviour: Two routes to food waste. Appetite 2016, 96, 7-17. [CrossRef]

12. Visschers, V.H.M.; Wickli, N.; SIegrist, M. Sorting out food waste behaviour: A survey on the motivators and barriers of self-reported amounts of food waste in households. J. Environ. Psychol. 2016, 45, 66-78. [CrossRef]

13. Secondi, L.; Principato, L.; Ruini, L.; Guidi, M. Reusing food waste in food manufacturing companies: The case of the tomato-sauce supply Chain. Sustainability 2019, 11, 2154. [CrossRef]

14. Byker, C.J.; Farris, A.R.; Marcenelle, M.; Davis, G.C.; Serrano, E.L. Food Waste in a School Nutrition Program After Implementation of New Lunch Program Guidelines. J. Nutr. Educ. Behav. 2014, 46, 406-411. [CrossRef]

15. Katajajuuri, J.M.; Silvennoinen, K.; Hartikainen, H.; Heikkilä, L.; Reinikainen, A. Food waste in the Finnish food chain. J. Clean. Prod. 2014, 73, 322-329. [CrossRef]

16. Scholz, K.; Eriksson, M.; Strid, I. Carbon footprint of supermarket food waste. Resour. Conserv. Recycl. 2015, 94, 56-65. [CrossRef]

17. Parizeau, K.; Von Massow, M.; Martin, R. Household-level dynamics of food waste production and related beliefs, attitudes, and behaviors in Guelph, Ontario. Waste Manag. 2015, 35, 207-217. [CrossRef]

18. Lourenço, J.O.; Katz, I. Estudo dos diversos índices de perdas no manuseio e transporte de verduras, legumes e frutas relacionadas à gestão logística. Tékhne Lógos 2010, 2, 110-125. Available online: http:/ / revista.fatecbt.edu.br/index.php/tl/article/view/93/52 (accessed on 9 April 2021).

19. Brandão, J.B.; Arbage, A.P. A gestão da cadeia de suprimentos das redes regionais de varejo de frutas, legumes e verduras no Rio Grande do Sul: Um estudo multicaso. Extensão Rural. 2016, 23, 51-68. [CrossRef]

20. Belik, W.; Cunha, A.R.A.; Costa, L.A. Crise dos alimentos e estratégias para a redução do desperdício no contexto de uma política de segurança alimentar e nutricional no Brasil. Planej. Políticas Públicas 2012, 38, 107-132.

21. Fagundes, P.; Silva, R.; Nachiluk, K.; Mondini, L. Aproveitamento dos resíduos gerados no entreposto terminal de São Paulo da CEAGESP. Inf. Econ. 2012, 42, 65-73. Available online: http:/ / www.iea.sp.gov.br/out/LerTexto.php?codTexto=12402 (accessed on 9 April 2021).

22. Prado, L.S.; Ceribeli, H.B.; Merlo, E.M. Como os varejistas podem contribuir para a redução de perdas de alimentos? Um estudo no pequeno varejo alimentar. Rev. Ciênc. Gerenc. 2011, 15, 45-64. 
23. Tofanelli, M.B.D.; Fernandes, M.S.; Carrijo, N.B.; Martins Filho, O.B. Levantamento de perdas em hortaliças frescas na rede varejista de Mineiros. Hortic. Bras. 2009, 27, 116-1209. [CrossRef]

24. Almeida, E.I.B.; Ribeiro, W.S.; Costa, L.C.; Lucena, H.H.; Barbosa, J.A. Levantamento de perdas em hortaliças frescas na rede varejistas de Areia (PB). Rev. Bras. Agropecu. Sustent. 2012, 2, 53-60.

25. Nantes, J.F.D.; Leonelli, F.C.V. A estruturação da cadeia produtiva de vegetais minimamente processados. FAE 2000, 3, 61-69.

26. Teller, C.; Holweg, C.; Reiner, G.; Kotzab, H. Retail store operations and food waste. J. Clean. Prod. 2018, 185, 981-997. [CrossRef]

27. Weiss, C.; Santos, M. A Logística de Distribuição e as Perdas ao Longo da Cadeia Produtiva das Frutas Frescas. Presented at the XI Congresso Virtual Brasileiro de Administração (CONVIBRA), Rio Grande do Sul, Brazil. 2014. Available online: https:/ / convibra.org/congresso/res/uploads/pdf/2014_30_10162.pdf (accessed on 9 April 2021).

28. EMBRAPA. Perdas e Desperdício de Alimentos. 2018. Available online: https://www.embrapa.br/tema-perdas-e-desperdiciode-alimentos/sobre-o-tema (accessed on 24 April 2021).

29. Cicatiello, C.; Franco, S. Disclosure and assesment of unrecorded food waste at retail stores. J. Retail. Consum. Serv. 2020, 52, 101932. [CrossRef]

30. Santos, C.F.; Cardoso, R.C.V.; Borges, I.M.P.; Almeida, A.C.; Andrade, E.S.; Ferreira, I.O.; Ramos, L.C. Post-harvest losses of fruits and vegetables in supply centers in Salvador, Brazil: Analysis of determinants, volumes and reduction strategies. Waste Manag. 2020, 101, 161-170. [CrossRef]

31. Porat, R.; Lichter, A.; Terry, L.A.; Harker, R.; Buzby, J. Postharvest losses of fruti and vegetables during retail and in consumers' homes: Quantifications, causes, and means of prevention. Postharvest Biol. Technol. 2018, 139, 135-149. [CrossRef]

32. Ceccato, C.; Basso, C. Avaliação das perdas de frutas, legumes e verduras em supermercado de Santa Maria, RS. Rev. Eletrônica Discip. Sci. 2011, 12, 127-137.

33. Tofanelli, M.D.B.; Fernandes, M.S.; Martins Filho, O.B.; Carrijo, N.B. Perdas de frutas frescas no comércio varejista de Mineiros-GO: Um estudo de caso. Rev. Bras. Frutic. 2007, 29, 513-517. [CrossRef]

34. Ribeiro, T.P.; Lima, M.A.C.; Souza, S.O.; Araújo, J.L. Perdas pós-colheita em uva de mesa registradas em casa de embalagem em mercado distribuidor. Rev. Caatinga 2014, 27, 67-74.

35. Buzby, J.C.; Hyman, J. Total and per capita value of food loss in the United States. J. Food Policy 2012, 37, 561-570. [CrossRef]

36. Garrone, P.; Melacini, M.; Perego, A. Opening the black box of food waste reduction. Food Policy 2014, 46, 129-139. [CrossRef]

37. Halloran, A.; Clement, J.; Kornum, N.; Bucatariu, C.; Magid, J. Addressing food waste reduction in Denmark. Food Policy 2014, 49 , 294-301. [CrossRef]

38. Quested, T.E.; Marsh, E.; Stunell, D.; Parry, A.D. Spaghetti soup: The complex world of food waste behaviours. Resour. Conserv. Recycl. 2013, 79, 43-51. [CrossRef]

39. Papargyropoulou, E.; Lozano, R.; Steinberger, J.K.; Wright, N.; Ujang, Z. The food waste hierarchy as a framework for the management of food surplus and food waste. J. Clean. Prod. 2014, 76, 106-115. [CrossRef]

40. Stefan, V.; Herpen, E.; Tudoran, A.A.; Lähteenmäki, L. Avoiding food waste by Romanian consumers: The importance of planning and shopping routines. Food Qual. Prefer. 2013, 28, 375-381. [CrossRef]

41. Betz, A.; Buchli, J.; Gobel, C.; Muller, C. Food waste in the Swiss food service industry-Magnitude and potential for reduction. Waste Manag. 2015, 35, 218-226. [CrossRef] [PubMed]

42. Sonnino, R.; McWilliam, S. Food waste, catering practices and public procurement: A case study of hospital food systems in Wales. Food Policy 2011, 36, 823-829. [CrossRef]

43. Aschemann-witzel, J.; Hooge, I.E.; Rohm, H.; Normann, A.; Bossle, M.B.; Grønhøj, A.; Oostindjer, M. Key characteristics and success factors of supply chain initiatives tackling consumer-related food waste-A multiple case study. J. Clean. Prod. 2017, 155, 33-45. [CrossRef]

44. Marchetto, A.M.P.; Ataide, H.H.; Masson, M.L.F.; Pelizer, L.H.; Pereira, C.H.C.; Sendão, M.C. Avaliação das partes desperdiçadas de alimentos no setor de hortifruti visando seu reaproveitamento. Rev. Simbio-Logias 2008, 1, 1-14.

45. Cronin, P.; Ryan, F.; Coughlan, M. Undertaking a literature review: A step-by-step approach. Br. J. Nurs. 2008, 17, 38-43. [CrossRef]

46. Pagani, R.N.; Kovaleski, J.L.; Resende, L.M. Methodi Ordinatio: A proposed methodology to select and rank relevant scientific papers encompassing the impact factor, number of citation, and year of publication. Scientometrics 2015, 105, 2109-2135. [CrossRef]

47. Yin, R.K. Applications of Case Study Research; SAGE: Thousand Oaks, CA, USA, 2001.

48. Bardin, L. Análise de Conteúdo; Content Analysis; Almedina: São Paulo, Brazil, 2016.

49. Mittal, A.; Gibson, N.O.; Krejci, C.C.; Marusak, A.A. Crowd-shipping for urban food rescue logistics. Int. J. Phys. Distrib. Logist. Manag. 2021. [CrossRef] 